\title{
EPC1 wt Allele
}

National Cancer Institute

\section{Source}

National Cancer Institute. EPC1 wt Allele. NCI Thesaurus. Code C111956.

Human EPC1 wild-type allele is located in the vicinity of $10 \mathrm{p} 11$ and is approximately $111 \mathrm{~kb}$ in length. This allele, which encodes enhancer of polycomb homolog 1 protein, is involved in both the regulation of histone acetylation and gene transcription. A fusion of this gene and the PHF1 gene may be associated with low-grade endometrial stromal sarcomas. 